\title{
The Exopolysaccharides of Klebsiella Serotype 2 Strains as Substrates for Phage-induced Polysaccharide Depolymerases
}

\author{
By I. W. SUTHERLAND \\ Department of Microbiology, University of Edinburgh, Edinburgh, EH9 ${ }_{3} \mathrm{JG}$
}

(Accepted for publication 15 November 1971)

SUMMARY

\begin{abstract}
A phage-induced enzyme has been used to hydrolyse the exopolysaccharides prepared from nine Klebsiella serotype 2 strains. In each case, the major product was a tetrasaccharide with chemical composition corresponding to the carbohydrate repeating unit of the polysaccharide. The tetrasaccharides also contained formate, sometimes with acetate or pyruvate. As the terminal reducing sugar in each tetrasaccharide was mannose, the enzyme is a mannosidase hydrolysing the D-mannosyl I $\rightarrow 4$ D-glucose linkage.

The enzyme is highly specific, being inactive against carboxyl-reduced type 2 polysaccharide and against polysaccharides from a number of other Klebsiella strains of different serotype. In contrast, similar phage-induced enzymes from Klebsiella aerogenes serotype 54 strains hydrolyse both type 2 and type 54 polysaccharides, yielding the same products from type 2 material as does the homologous enzyme. No further polysaccharides among those currently tested acted as substrates for the phage-induced enzymes.
\end{abstract}

\section{INTRODUCTION}

Exopolysaccharides (capsules or slime) from several bacterial species are the substrates for soluble enzymes isolated from bacteriophage-infected bacterial cultures. In some such systems, despite a dramatic drop in the viscosity of the polysaccharide solutions following addition of enzyme, no hydrolysis products have been identified (Adams \& Park, 1956; Eklund \& Wyss, 1962). The enzymes induced by several phages in Klebsiella aerogenes type 54 cultures hydrolysed the polysaccharide from this strain, producing a tetrasaccharide corresponding to the repeating unit of the polymer (Sutherland, 1967). Subsequently the oligosaccharide was shown to contain acetate and formate (Sutherland \& Wilkinson, 1968; Sutherland, 1970).

The isolation of a phage inducing polysaccharase formation in a Klebsiella pneumoniae type 2 strain was reported by Watson (I966). The enzyme had no effect on bacterial viability but removed the capsules and also affected the immunochemical reactions of the polysaccharide. Polysaccharides from four different Klebsiella type 2 strains all contained the same tetrasaccharide repeating unit (Fig. I; Gahan, Sandford \& Conrad, I967). Results from a further strain indicated that some variation in polysaccharide structure might occur, although the monosaccharide composition remained constant (Park, Eriksen \& Henriksen, I967). Further indications that polysaccharides might have constant carbohydrate structure but variable acyl substituents came from a preliminary examination of a number of Klebsiella strains of different serotype (Sutherland, I97I). The aim of the present work was to determine the effect of a phage-induced enzyme on the capsular polysaccharides isolated from Klebsiella type 2 strains and on others known to possess structural similarities. 


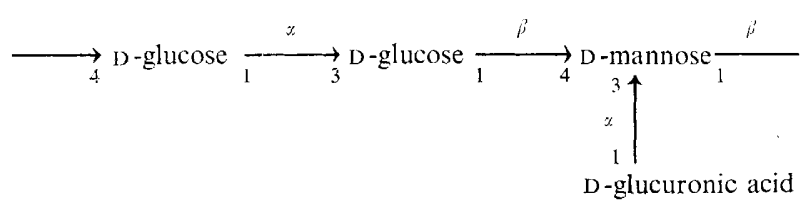

Fig. I. The structure of the repeating unit of serotype 2 capsular polysaccharide of Klebsiella aerogenes. (Gahan et al. 1967).

\section{METHODS}

Bacterial strains. The four strains of Klebsiella type 2 for which the structure of the polysaccharide has already been established (Gahan, Sandford \& Conrad, 1967) were obtained from the National Collection of Type Cultures, Colindale, London. These were strains 243, 418, 5505 and 9505. Strain 22 was provided by Dr D. G. McPhee, La Trobe University, Melbourne, Australia and strains 2S, 2534, 2895 and 2930 came from Dr G. Hermann, Center for Disease Control, Atlanta, Georgia, U.S.A. Strains AI and A3 were departmental cultures of serotypes I and 54 respectively.

Cultures were maintained on nutrient agar slopes in screw-capped vials. The polysaccharides were prepared from solid or liquid cultures in nitrogen-deficient medium (Sutherland \& Wilkinson, 1965) and purified as described by Dudman \& Wilkinson (1956). Some preparations were purified further by digestion with pronase.

Bacteriophage. Phage $\mathrm{F}_{40}$ (Watson, I966) was routinely prepared using cultures of strain 243; enzyme was prepared from phage-infected cultures of strain 243 or 418 as described for other phage-induced polysaccharide depolymerases (Sutherland, I967) and partially purified by ammonium sulphate precipitation and chromatography on DEAE-cellulose. Preparations from either host strain were identical in their activities. The preparation of polysaccharide-depolymerases (fucosidases) from phages F3I, 34 and 39 cultured on strain A3 has already been described (Sutherland, 1967).

Analysis techniques. Monosaccharides were determined on unhydrolysed material by the cysteine/sulphuric acid reaction for hexoses (Dische, Shettles \& Osnos, I949) and the carbazole reaction for uronic acid (Bitter \& Muir, I962). Hydrolysates of polysaccharides or oligosaccharides $\left(\mathrm{N}-\mathrm{H}_{2} \mathrm{SO}_{4}\right.$ at $100^{\circ}$ for $\left.\mathrm{I} 6 \mathrm{~h}\right)$ were neutralized with Amberlite IR4IO resin $\left(\mathrm{HCO}_{3}\right.$ form) and used to determine glucose and galactose with the respective oxidase reagents. The mannose content was calculated by difference from the total hexose values. Reducing sugar in enzymatic hydrolysates was measured by the Somogyi (1945) method.

Acetyl and pyruvyl contents were determined by micro-modifications of the hydroxamic acid and dinitrophenylhydrazine methods respectively (Hestrin 1949; Sloneker \& Orentas I962). Formate was assayed enzymatically with formate dehydrogenase (Quayle, I966) and also colorimetrically by the procedure of Grant (1948) if acetate was known to be absent. Acetate and formate derived from polysaccharides were characterized by the technique of Thomson (195I) involving preparation of hydroxamic acid derivatives and chromatography in solvent B. Chromatograms were developed with $10 \%(\mathrm{w} / \mathrm{v})$ aqueous $\mathrm{FeCl}_{3}$ solution. Pyruvate was identified by preparation of the dinitrophenylhydrazone and chromatography in solvent A along with authentic standards.

Partial acid hydrolysis. Approximately $40 \mathrm{mg}$. of each polysaccharide was dissolved in $20 \mathrm{ml} .0 .5 \mathrm{~N}-\mathrm{H}_{2} \mathrm{SO}_{4}$ in a tightly stoppered tube and heated at $100^{\circ}$ for $30 \mathrm{~min}$. The hydrolysates were neutralized with saturated $\mathrm{Ba}(\mathrm{OH})_{2}$ solution, filtered and concentrated under reduced pressure. The syrups so obtained were applied to Whatman $3 \mathrm{MM}$ paper and sub- 
jected to paper electrophoresis. After staining of guide strips with alkaline silver nitrate solution, fractions were eluted and compared by paper chromatography (solvents B and C).

Enzymatic hydrolysis. Samples of each polysaccharide ( $10 \mathrm{mg}$ ) were dissolved in I $\mathrm{ml}$ of $0.001 \mathrm{M}$-phosphate buffer $\left(\mathrm{pH} 7{ }^{\circ} \mathrm{O}\right)$ and sufficient depolymerase enzyme added to give maximal hydrolysis in $20 \mathrm{~h}$ at $20^{\circ}$. Microbial growth was inhibited by the addition of toluene. Hydrolysates were examined by paper chromatography (solvent D) or paper electrophoresis. When the enzymatic hydrolysis was complete, as determined by following release of reducing material, the solutions were dialysed against distilled water to separate the products from enzyme protein and undigested polymer. The diffusible material, comprising 80 to $90 \%$ of the original polysaccharide, was concentrated under reduced pressure at 40 to $50^{\circ}$ and the resultant syrups subjected to paper electrophoresis. Guide strips were stained to locate oligosaccharides. Because of the presence of variable amounts of salts in polysaccharide preparations, preparative amounts of the oligosaccharides were always separated by electrophoresis then by paper chromatography. The reduction in viscosity was followed using an Ostwaldtype viscometer at $30^{\circ}$.

Paper chromatography and paper electrophoresis. The following solvent systems were used for descending paper chromatography on Whatman no. I paper. Solvent A: butan-I-olpyridine-water (6:4:3, by vol.) (Whistler \& Conrad, I954); solvent B: butan-I-ol-acetic acid-water (4: I:5, by vol.) (Partridge, I946); solvent C: ethyl acetate-acetic acid-formic acid-water (I8:3:I:4, by vol.) (Feather \& Whistler, I962); solvent D: ethyl acetatepyridine-acetic acid-water (5:5:1:3, by vol.) (Fischer \& Dörfel, 1955). Paper electrophoresis was performed in pyridine-acetic acid buffer ( $\mathrm{pH} 5 \cdot 3$ ). A current of 80 to $100 \mathrm{~mA}$ was applied at $3000 \mathrm{~V}$ using a Locarte (London) paper electrophoresis equipment with $70 \times 20 \mathrm{~cm}$ cooled plate area, for $3 \mathrm{~h}$ to separate oligosaccharides, for $30 \mathrm{~min}$ to remove salts or enzyme proteins.

Borohydride reduction. The terminal reducing sugars of the oligosaccharides were determined by borohydride reduction (Sutherland, 1967). After removal of the salts by paper electrophoresis, material was eluted and hydrolysed $\left(\mathrm{N}-\mathrm{H}_{2} \mathrm{SO}_{4}\right.$ for $\left.\mathrm{I} 6 \mathrm{~h}\right)$. Sugar alcohols were identified by chromatography of hydrolysates in solvents $\mathrm{A}$ and $\mathrm{C}$.

\section{RESULTS}

Composition of the exopolysaccharides. Acid hydrolysates from each polysaccharide were neutralized and examined by paper chromatography in solvents $A$ and D. In all the preparations from type 2 strains, glucose, mannose and glucuronic acid were detected, the most intense spot being glucose. This agrees with the results of Gahan et al. (I967). Traces of galactose were also observed in a few hydrolysates. These were thought to originate from contaminating lipopolysaccharide which is known to contain considerable quantities of galactose (Koeltzow, Epley \& Conrad, 1968). Galactose was not found in the oligosaccharides obtained by enzymatic hydrolysis. The polysaccharides of type I and type 54 both contained L-fucose, D-glucose and D-glucuronic acid. Analyses for acetate, formate and pyruvate were made on all the polysaccharides. These results, together with determinations for the sugars detected chromatographically are shown in Table $\mathbf{I}$. It is clear that all the type 2 polysaccharides contain the same monosaccharides-glucose, mannose and glucuronic acid - in the same approximate molar ratio of 2: I: I respectively. Probably, all possessed the tetrasaccharide repeating unit described by Gahan et al. (1967) (Fig. I). Further evidence was obtained from partial acid hydrolysates. Each yielded the same products, a series of charged oligosaccharides indistinguishable from those previously described by Gahan et al. 
Table I. The composition of Klebsiella type 2 and other capsular polysaccharides (results as \% dry weight)

\begin{tabular}{|c|c|c|c|c|c|c|c|}
\hline Type & Strain & D-Glucose & Mannose & $\begin{array}{l}\text { Glucuronic } \\
\text { acid }\end{array}$ & Pyruvate & Formate & Acetate \\
\hline & $2 \mathrm{~S}$ & $41 \cdot 4$ & 19.9 & $26 \cdot 4$ & 0.1 & $4^{\cdot I}$ & O.I \\
\hline & 418 & $42 \cdot 4$ & 20.5 & $23 \cdot I$ & 0 & $3 \cdot 9$ & 0 \\
\hline 2 & 5505 & $43 \cdot 0$ & $20 \cdot 7$ & $2 I \cdot 6$ & 0.3 & 3.9 & 0 \\
\hline & 9504 & $45 \cdot 3$ & 23.5 & $20 \cdot 8$ & 0.7 & $4 \cdot 2$ & 0 \\
\hline & 2534 & $46 \cdot 0$ & $2 I \cdot 6$ & $25 \cdot 7$ & 0.6 & $5 \cdot 0$ & 0 \\
\hline & 2930 & $43 \cdot 0$ & $20 \cdot 5$ & $24 \cdot I$ & 0 & $5 \cdot 9$ & $8 \cdot 3$ \\
\hline & 2895 & $46 \cdot 0$ & $22 \cdot I$ & $24 \cdot 6$ & $0 . I$ & $4 \cdot 6$ & $4 \cdot 5$ \\
\hline & 243 & $46 \cdot 3$ & $2 I \cdot 9$ & $22 \cdot 9$ & 0 & $4 \cdot 8$ & $8 \cdot I$ \\
\hline & 22 & $36 \cdot 4$ & $20 \cdot 3$ & $19 \cdot 7$ & $5 \cdot 2$ & 3.9 & 0 \\
\hline \multicolumn{8}{|c|}{ Fucose } \\
\hline I & A I & $43 \cdot 0$ & $19 \cdot 3$ & $23 \cdot 4$ & 10.3 & 0 & 0 \\
\hline 54 & A 3 & 37.9 & 18.8 & $23 \cdot 2$ & 0 & $4 \cdot 6$ & $4 \cdot 5$ \\
\hline
\end{tabular}

(1967). The carbohydrate composition of all the type 2 preparations was therefore similar if not identical.

When eight type 2 polysaccharide preparations were examined for non-carbohydrate constituents, much greater variation was noted. Although all the polymers contained formate, only one contained pyruvate. Acetate was found in three polysaccharides. These results were confirmed by the preparation and chromatography of the appropriate derivatives. The type 2 polysaccharides can therefore be separated into three groups: (i) those polymers which contain formate; (ii) the polysaccharides which contain formate and acetate; and (iii) the single preparation in which both formate and pyruvate are detected. There was no indication that any other non-carbohydrate residues were associated with the type 2 Klebsiella exopolysaccharides.

Although type I and type 54 material contained the same monosaccharides, confirming the earlier results of Dudman \& Wilkinson (1956), significant differences were seen in their acyl substituents. The type I polymer contained pyruvate, while the type 54 polysaccharide was both acetylated and formylated.

Polysaccharides as phage enzyme substrates. All the type 2 Klebsiella strains were susceptible to infection with phage $\mathrm{F}_{40} \mathrm{O}$. When phage plaques or areas of confluent lysis were examined, they were surrounded by a zone which was partially cleared. These zones contained viable, non-capsulate bacteria. On subculture they proved to be identical with the original bacteria, being surrounded with capsules and free from phage. As phage F40 was known to produce a polysaccharide depolymerase (Watson, I966) this indicated that all the capsular polysaccharides were probably substrates for the enzyme. When polysaccharide solutions were treated with the partially purified phage F40-induced depolymerase enzyme, there was a very marked reduction in the viscosity of the solution. This was accompanied by the release of reducing material. Typical results for the release of reducing material from solutions of exopolysaccharide (strain 4I8) on enzyme treatment are shown (Fig. 2). Similar results were obtained from all type 2 polysaccharide preparations, within the limits of experimental error, no differences were detected in the time required for $50 \%$ drop in solution viscosities. The type 2 strains and the type $I$ strain were insensitive to the three phages (F3I, 34, 39) having type 54 as their normal host. No hydrolytic activity was found using a number of other Klebsiella exopolysaccharides nor was any found using carboxyl-reduced 


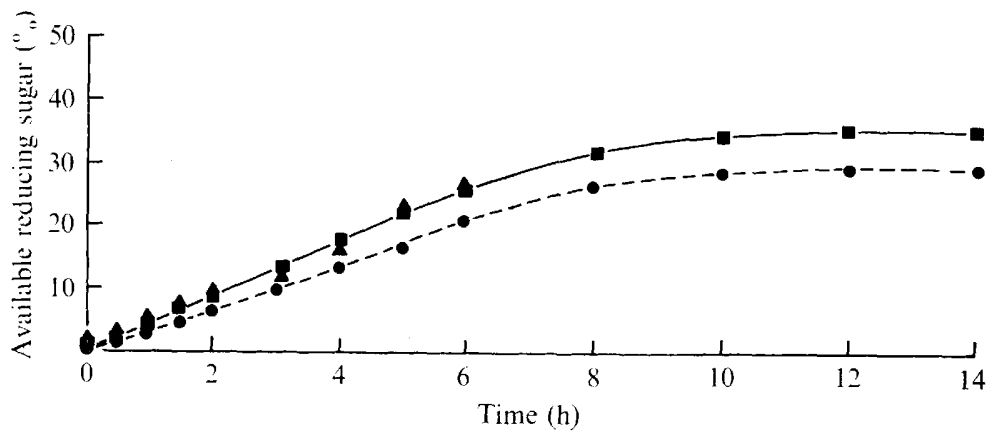

Fig. 2. The release of reducing material from Klebsiella polysaccharide solutions on treatment with phage enzymes. Polysaccharide solutions $(4 \mathrm{mg} / \mathrm{ml})$ were incubated at $30^{\circ}$ with enzymes $(0 \cdot \mathrm{I} \mathrm{mg}$ protein $/ \mathrm{ml}$ ) and samples removed at intervals for determination of reducing sugars. $\mathbf{\square}$, Klebsiella aerogenes type 54 polysaccharide and type 54 enzyme; 0 , Klebsiella type 2 polysaccharide and type 54 enzyme: $\boldsymbol{\Lambda}$, Klebsiella type 2 polysaccharide and type 2 enzyme.

Klebsiella material of serotype 2. As phages F3I, 34 and 39, isolated using Klebsiella aerogenes type 54 as host bacteria, showed partial clearing of the type 2 strains on solid media, enzymes prepared from phage-infected type 54 cells were also tested. The effect was the same as that observed with the F40-induced enzyme. The viscosity of the solutions fell and reducing material was liberated (Fig. 2). No fall in viscosity of solutions of polysaccharides from the type I strain was seen despite the known chemical similarities and serological crossreactions of this polymer. Attempts to isolate similar enzymes from non-infected bacteria were unsuccessful.

Isolation and characterization of enzyme products. The products from hydrolysis of strain 22 polysaccharide were separated into two fractions (PI and P2) which could not be resolved further by paper chromatography. The strains containing formate as the sole acyl group produced a single fragment (PI) on electrophoresis and it, too, could not be resolved further by chromatography. The acetylated polymers yielded approximately equal amounts of two oligosaccharides ( $\mathrm{P}_{1}$ and $\mathrm{P}_{3}$ ) which were separable by paper chromatography in solvent $\mathrm{D}$. Exactly the same products were obtained from the respective polysaccharides when $\mathrm{F}_{3} \mathrm{I}$, $F_{34}$ or $F_{40}$-induced enzymes were used.

Examination of the oligosaccharides obtained by enzymatic hydrolysis in this way showed that the slower-moving (chromatographically) fractions from strain 22 and the acetylated strains were indistinguishable and also appeared to be identical with the single product from the strains containing formate as the sole acyl substituent. Hydrolysates of all three fragments contained glucose, mannose and glucuronic acid in the approximate molar ratio of $2: \mathrm{I}: \mathrm{I}$. All the mannose in each oligosaccharide was reduced to mannitol by treatment with sodium borohydride, indicating that each was a tetrasaccharide in which mannose was the terminal reducing sugar. The properties of the three tetrasaccharides and the polymers from which they were produced are listed in Table 2. Attempts to identify the sites of acyl groups are continuing.

\section{DISCUSSION}

Capsular polysaccharides prepared from nine different strains of Klebsiella type 2 were all hydrolysed by a phage-induced enzyme. As judged by similar rates of release of reducing material and of reduction of solution viscosity, the differing acyl groups present on the polysaccharides did not affect the enzyme activity. Attempts to find other substrates for the 
Table 2. The properties of oligosaccharides isolated from enzymatic hydrolysates

\begin{tabular}{|c|c|c|c|c|c|c|c|c|c|}
\hline \multirow[b]{2}{*}{$\begin{array}{l}\text { Oligosac- } \\
\text { charide }\end{array}$} & \multirow[b]{2}{*}{ Source } & \multicolumn{6}{|c|}{ Components $\mu$ moles/ $100 \mu 1$ solution* } & \multirow[b]{2}{*}{$\mathbf{M}_{\text {GlcA }} \dagger$} & \multirow[b]{2}{*}{$\operatorname{RgIc}^{\text {(Solvent D) }}$} \\
\hline & & Glucose & Mannose & $\begin{array}{l}\text { Glucuronic } \\
\text { Acid }\end{array}$ & Formate & Acetate & Pyruvate & & \\
\hline$P_{I}$ & $\begin{array}{c}\text { All type } 2 \\
\text { polysac- } \\
\text { charides }\end{array}$ & $2 \cdot 34$ & $I \cdot 29$ & $I \cdot 30$ & $I \cdot 27$ & 0 & 0 & 0.45 & 0.36 \\
\hline $\mathbf{P}_{2}$ & 22 only & $2 \cdot 92$ & $I \cdot 43$ & $I \cdot 50$ & 0.02 & o & $I \cdot 44$ & 0.94 & 0.66 \\
\hline $\mathbf{P}_{3}$ & $\begin{array}{r}243 \\
2930 \\
2895\end{array}$ & $2 \cdot 97$ & I 65 & $I \cdot 5 I$ & $\mathrm{I} \cdot 58$ & I.54 & 0 & $0.4 I$ & 0.45 \\
\hline
\end{tabular}

* Figures are given for material from strains 418,22 and 243 respectively. Other preparations showed no significant differences from these in the molar ratios of the constituents.

$\dagger$ Electrophoretic mobility relative to glucuronic acid. $\left(\mathrm{M}_{\mathrm{GleA}}\right)$.

enzyme were unsuccessful. Carboxyl reduction, the conversion of the glucuronic acid residues to glucose, leaves the polymer structure intact. This change was sufficient to render type 2 polysaccharide resistant to enzymatic hydrolysis and thus defines further the substrate specificity of the phage-induced enzyme. It appears to be a mannosidase hydrolysing the mannosidic bond in polymers containing the sequence - D-glucuronosyl-D-mannosyl-Dglucose - identified by Gahan et al. (1967). It was not active against polysaccharides of types 30 and 69 which are known to cross-react serologically with type 2 Klebsiella strains (Dr I. Ørskov, personal communication). Either the serological cross-reaction is not due to the particular mannosidic bond, or the remaining glycosidic bonds and chemical structure of the polymers may be sufficiently different to account for the lack of enzyme action.

Surprisingly, phage-induced enzyme preparations from Klebsiella aerogenes type 54 also hydrolysed type 2 polysaccharides, forming the same products as the enzyme induced by phage in type 2 bacteria. This result could be due to (i) a gratuitous impurity in the type 54 enzyme preparations or (ii) a much lower substrate specificity in the type 54 enzyme systems. The latter is more probably true, as these enzymes had previously been shown to hydrolyse $K$. aerogenes type 54 polysaccharide, de-acylated polymer and oligosaccharides derived from it (Sutherland \& Wilkinson, I968) as well as hydrolysing the capsular polysaccharide of similar but not identical structure formed by Escherichia coli K27 (Sutherland, Jann \& Jann, 1970). Both the enzymes induced in Klebsiella type 2 bacteria and those isolated from phageinfected $K$. aerogenes type 54 cultures appear to be hydrolases. The hydrolysis products contained glucuronic acid and not a 4, 5 unsaturated uronic acid of the type formed by the eliminase acting on Xanthomonas phaseoli capsular polysaccharide (Lesley, I96I) and similar systems.

Of the nine serotype 2 Klebsiella strains examined, only one capsular polysaccharide was pyruvylated confirming the results of Gormus, Wheat \& Porter(I97I). Pyruvate is now known to be a common substituent of bacterial exopolysaccharides, having been identified in such polymers from Xanthomonas species (Orentas, Sloneker \& Jeanes, 1963); Escherichia coli (Lawson et al. 1969) and several other bacteria. Recently, Gormus et al. (1971) identified pyruvic acid as a component of exopolysaccharides from various Klebsiella species including serotypes I and $3-6$, but failed to find it in the polysaccharide of the one type 2 strain tested. The present study shows that not all strains of one serotype possess the same acyl substituents on their exopolysaccharides despite the probable constancy of the carbohydrate structure. Formate, previously identified as a component of Klebsiella aerogenes type 54 capsular material (Sutherland, 1970) is prevalent in type 2 polysaccharides as well. 
The author is grateful to Dr K. C. Watson for the gift of the phage culture and to Mrs I. C. Wright for technical assistance.

\section{REFERENCES}

Adams, M. H. \& PARK, B. H. (1956). An enzyme produced by a phage-host cell system. II. The properties of the polysaccharide depolymerase. Virology 2, 719-736.

Bitter, T. \& MurR, H. M. (I962). A modified uronic acid carbazole reaction. Analytical Biochemistry 4, $330-334$.

Dische, Z., Shettles, L. B. \& Osnos, M. (1949). New specific colour reactions of hexoses and spectrophotometric micromethods for their determination. Archives of Biochemistry and Biophysics 22, 169-1 86.

Dudman, W. F. \& WiLkinson, J. F. (1956). The composition of the extracellular polysaccharide of Aerobacter-Klebsiella strains. Biochemical Journal 62, 289-295.

EkLUND, C. \& WYSS, O. (1962). Enzyme associated with bacteriophage infection. Journal of Bacteriology 84 , I209-I 215.

FEATHER, M.S. \& WhisTLER, R.L. (I962). Isolation and characterisation of the principle hemicellulose from corn germ. Archives of Biochemistry and Biophysics. 98, I I I-I I 5 .

Fischer, F. G. \& Dörfel, H. (1955). Die papier-chromatographische Trennung and Bestimmung der Uronsäuren. Hoppe-Seyler's Zeitschrift für physiologische Chemie 301, 224-234.

GAHAN, L. C., SANDFord, P. A. \& ConRAD, H.E. (1967). The structure of the serotype 2 capsular polysaccharide of Aerobacter aerogenes. Biochemistry 6, 2755-2766.

GoRmus, B. J., WHEAT, R.W. \& PORTER, J.F. (I97I). Occurrence of pyruvic acid in capsular polysaccharides from various Klebsiella species. Journal of Bacteriology 107, I50-154.

Grant, W. M. (1948). Colorimetric micro-determination of formic acid based on reduction to formaldehyde. Analytical Chemistry 20, 267-269.

HestRIN, S. (1949). The reaction of acetylcholine and other carboxylic acid derivatives with hydroxylamine and its analytical application. Journal of Biological Chemistry 180, 249-26I.

Koeltzow, D. E., Epley, J. D. \& ConRAD, H. E. (I968). The lipopolysaccharides of Aerobacter aerogenes strains A3(SI) and NCTC243. Biochemistry 7, 2920-2928.

Lawson, C. J., Mcleary, C. W., Nakada, H. I., Rees, D. A., Sutherland, I. W. \& Wilkinson, J. F. (1969). Structural analysis of colanic acid from Escherichia coli by using methylation and base-catalysed fragmentation. Biochemical Journal 115, 947-958.

LESLEY, S. M. (196I). Degradation of the polysaccharide of Xanthomonas phaseoli by an extracellular bacterial enzyme. Canadian Journal of Microbiology 7, 81 5-825.

Orentas, D. G., Sloneker, J. H. \& Jeanes, A. (I963). Pyruvic acid content and constituent sugars of exocellular polysaccharides from different species of the genus Xanthomonas. Canadian Journal of Microbiology 9, 427-430.

Park, S. H., Eriksen, J. \& Henriksen, S. D. (1967). Structure of the capsular polysaccharide of Klebsiella pneumoniae type 2 (в). Acta pathologica et microbiologica scandinavica 69, 43I-436.

PARTRIDGE, S. M. (1946). Application of the paper partition chromatogram to the qualitative analysis of reducing sugars. Nature, London $\mathbf{1 5 8}, 270-271$.

QUAYLE, J. R. (1966). Formate dehydrogenase. In Methods in Enzymology, vol. 9, pp. 360-364. Edited by S. P. Colowick \& N. O. Kaplan. New York \& London: Academic Press.

SLONekER, J. H. \& ORENTAS, D. G. (1962). Pyruvic acid, a unique component of an exocellular bacterial polysaccharide. Nature, London 194, 478-479.

Somogyi, M. (1945). A new reagent for the determination of sugars. Journal of Biological Chemistry 160, 6I-69.

SUTHERLAND, I. W. (I967). Phage-induced fucosidases hydrolysing the exopolysaccharide of Klebsiella aerogenes type 54 (A3(SI)). Biochemical Journal 104, 278-285.

Sutherland, I. W. (1970). Formate, a new component of bacterial exopolysaccharides. Nature, London $228,280$.

SUtHERLAND, I. W. (197I). The occurrence of acyl groups in Klebsiella exopolysaccharides. Journal of General Microbiology 65, v.

SUTHERLAND, I. W., JANN, K. \& JANN, B. (1970). The isolation of O-acetylated fragments from the K antigen of Escherichia coli $08: \mathrm{K} 27(\mathrm{~A})$ by the action of phage-induced enzymes from Klebsiella aerogenes. European Journal of Biochemistry 12, 285-288.

SUTHERLAND, I. W. \& Wilkinson, J. F. (I965). Depolymerases for bacterial polysaccharides obtained from phage-infected bacteria. Journal of General Microbiology 39, 373-383. 
Sutherland, I. W. \& Wilkinson, J. F. (I968). The exopolysaccharide of Klebsiella aerogenes A3(si) (type 54). The isolation of $\mathrm{O}$-acetylated octasaccharide, tetrasaccharide and trisaccharide. Biochemical Journal $\mathbf{1 1 0}$, 749-754.

Thomson, A. R. (I95I). The separation of saturated mono-hydromaxic acids by partition chromatography on paper. Australian Journal of Scientific Research, B 4, I80-187.

Watson, K. C. (1966). The effect of polysaccharide depolymerising enzyme in gel diffusion and haemagglutination studies. Immunology ro, I 2 I-I 26.

Whistler, R. L. \& ConRAD, H. E. (1954). 2-o-(D-Galactopyranobyluronic acid)-L-rhamnose from okra mucilage. Journal of the American Chemical Society 76, 3544-3546. 